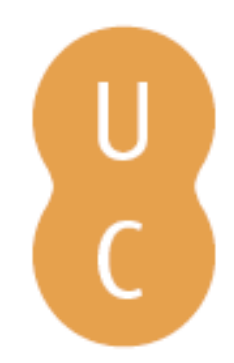

\title{
nombalina
}

\section{"Em torno da revisão do sistema eleitoral açoriano": uma visão desde as Relações Internacionais}

Autor(es): Rocha, Miguel

Publicado por: Imprensa da Universidade de Coimbra

URL

persistente: URI:http://hdl.handle.net/10316.2/47300

DOI: DOl:https://doi.org/10.14195/978-989-26-1849-4_9

Accessed : $\quad$ 26-Apr-2023 13:54:01

A navegação consulta e descarregamento dos títulos inseridos nas Bibliotecas Digitais UC Digitalis, UC Pombalina e UC Impactum, pressupõem a aceitação plena e sem reservas dos Termos e Condições de Uso destas Bibliotecas Digitais, disponíveis em https://digitalis.uc.pt/pt-pt/termos.

Conforme exposto nos referidos Termos e Condições de Uso, o descarregamento de títulos de acesso restrito requer uma licença válida de autorização devendo o utilizador aceder ao(s) documento(s) a partir de um endereço de IP da instituição detentora da supramencionada licença.

Ao utilizador é apenas permitido o descarregamento para uso pessoal, pelo que o emprego do(s) título(s) descarregado(s) para outro fim, designadamente comercial, carece de autorização do respetivo autor ou editor da obra.

Na medida em que todas as obras da UC Digitalis se encontram protegidas pelo Código do Direito de Autor e Direitos Conexos e demais legislação aplicável, toda a cópia, parcial ou total, deste documento, nos casos em que é legalmente admitida, deverá conter ou fazer-se acompanhar por este aviso.

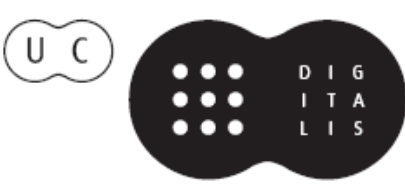


Euro-Atlântico:

Espaço de Diálogos

Isabel Maria Freitas Valente

Iranilson Buriti de Oliveira

(Coord)

\section{VISÕES \\ INTERDISCIPLINARES \\ DA EUROPA \\ E DO MUNDO:}

uma experiência de convergência

disciplinar em homenagem a

Maria Manuela Tavares Ribeiro

Alexandra Aragão

Isabel Maria Freitas Valente

Dulce Lopes

(org.)

Editora da Universidade Federal de Campina Grande

Imprensa da Universidade de Coimbra

2019 


\title{
"EM TORNO DA REVISÃO DO SISTEMA ELEITORAL AÇORIANO", UMA VISÃO DESDE AS RELAÇÕES INTERNACIONAIS
}

\author{
Miguel Rocha
}

A Constituição portuguesa de 1976 consagrou Portugal como um Estado unitário, com duas regiões autónomas - os Açores e a Madeira - dotadas de estatutos político-administrativos e órgãos políticos próprios (artigo $6^{\circ}$ ). Podemos considerar esta experiência um dos maiores legados da democracia portuguesa, não obstante algumas tensões existentes entre os poderes regionais e o poder central. A edificação desta inovação constitucional ocorreu num período histórico específico, quando se pretendia consolidar as instituições democráticas e o país ainda lidava com reivindicações independentistas nestes arquipélagos, vindas de sectores alarmados com a radicalização do processo revolucionário português. A transferência de competências do poder central para o regional, tal como a existência de órgãos regionais com legitimidade democrática, consolidaram a unidade nacional e o respeito pelas suas singularidades. Por outro lado, a adesão de Portugal à então CEE e a participação açoriana e madeirense neste novo projecto nacional representaram um ponto de viragem na história destas populações regionais, que muito beneficiaram com a aplicação dos fundos europeus, superando a realidade de subdesenvolvimento económico que as caracterizava até 1986.

O texto do Professor Carlos Amaral versou a urgência de uma revisão do sistema eleitoral dos Açores para a Assembleia Regional, dada a premência de substituir um sistema desadequado da realidade açoriana. Deste modo, Carlos Amaral debruçou-se, durante a sua reflexão, sobre as suas contradições: a primeira, no facto de poder resultar em legitimidades contraditórias e conflituosas quanto à governação - um partido pode vencer as eleições por votos populares, mas eleger menos deputados para a Assembleia Regional; a outra advém de "consagrar" dois tipos de parlamentares - os deputados de representação territorial 
(dois deputados por cada ilha) e os de representação demográfica (eleitos em função do número de eleitores inscritos em cada Ilha), reunindo-os na mesma Assembleia. Propôs então a adopção do sistema bicamaral na Região como alternativa desejável: uma Câmara Alta, para a qual seriam eleitos dois deputados por cada ilha (18), juntando-se mais dois pelo círculo da emigração; uma Câmara Baixa, cuja eleição seria determinada por critérios de proporcionalidade demográfica. Esta reorganização política implicaria uma redistribuição de competências por cada Câmara: para a Câmara Alta, as questões relacionadas com a governabilidade (moções de confiança e de censura, aprovação de Orçamentos regionais), revisão do Estatuto de autonomia, produção legislativa, etc.; para a Câmara Baixa, para além destas problemáticas, deverá incidir ainda sobre os aspectos de natureza política que se prendem com o debate político regional. $\mathrm{O}$ autor enfatizou ainda que tais alterações não acarretarão despesa adicional para os contribuintes.

Assim, estamos diante de uma proposta de ruptura com implicações no âmbito constitucional. Trata-se de uma proposta inovadora, mas como o próprio reconheceu, de difícil exequibilidade no actual contexto político-constitucional; todavia, urge uma "refundação" do actual sistema autonómico, já "obsoleto e ultrapassado em termos europeus". 